\title{
Strategi Meningkatkan Kompetensi 4C (Critical Thinking, Creativity, Communication, \& Collaborative)
}

\author{
Partono*, Hesti Nila Wardhani, Nuri Indah Setyowati*, Annuriana Tsalitsa, Siti Nurrahayu \\ Putri \\ Fakultas Tarbiyah, Institut Agama Islam Negeri (IAIN) Kudus \\ Jl. Conge Ngembalrejo, Kudus 59322, Jawa Tengah. \\ *Corresponding Author.e-mail: partono@iainkudus.ac.id, nuriindahsetyowati399@gmail.com
}

\begin{abstract}
Abstrak
Tujuan dari penelitian ini untuk mengetahui strategi dalam meningkatkan kompetensi 4C (Critical Thinking, Creativity, Communication, \& Collaborative). Kompetensi 4C sangat diperlukan di masa mendatang dalam mencari tenaga kerja karena persaingan semakin ketat. Banyak juga tugas-tugas yang seharusnya dilakukan oleh manusia tetapi tergantikan dengan robot. Hal tersebut dikarenakan pada abad ke-21 ini perkembangan teknologi semakin pesat. Sehingga perlu ada keterampilan yang tidak dimiliki oleh robot yaitu keterampilan kompetensi 4C. SIDH (Sekolah Indonesia Den Haag) merupakan salah satu sekolah Indonesia luar negeri yang sangat memperhatikan kompetensi 4C. Pada sekolah tersebut selalu berupaya untuk meningkatkan kompetensi 4C dengan berbagai strategi. Dengan cara diskusi saat pembelajaran, mengikuti ekstrakulikuler, dan bekerjasama dengan pusdatin. Meningkatkan kompetensi $4 \mathrm{C}$ di SIDH juga dapat melalui melalui pembelajarn PAI. Pada penelitian ini menggunakan metode diskriptif kualitatif. Metode ini memberikan data berupa data verbal. Teknik pengumpulan data yang digunakan yaitu wawancara dengan guru di SIDH yaitu Safreni Candra Sari dan Ponco Handayawati melalui media aplikasi zoom dan dokumen yang diperoleh berupa gambar atau foto yang menunjukkan beberapa kegiatan di SIDH.
\end{abstract}

Kata Kunci: strategi, kompetensi 4 , pembelajaran PAI

\section{Strategies to Improve 4C Competencies (Critical Thinking, Creativity, Communication \& Collaborative)}

\begin{abstract}
The purpose of this research is to find out strategies to improve $4 C$ competence (Critical Thinking, Creativity, Communication, \& Collaborative). $4 C$ competence is needed in the future is looking for workers because the competition is getting tougher. There are also many tasks that should be done by humans but are replaced by robots. This is because in the 21 st century the development of technology is increasingly rapid. So there need to be skills that robots don't have, namely $4 C$ competency skills. SIDH (Sekolah Indonesia Den Haag) is one of the Indonesian overseas schools that pays attention to $4 C$ competencies. The school always tries to improve $4 C$ competence with various strategies. For example, through discussions during learning, taking extracurricular activities, and collaborating with Pusdatin. Improving 4 C competence at SIDH can also be done through learning PAI. This study using a qualitative descriptive method. This method provides data in the form of verbal data. Data collection techniques used were interviews with teachers at SIDH, namely Safreni Candra Sari and Ponco Handayawati through the zoom application media and documents obtained in the form of pictures or photos showing some of the activities at SIDH.
\end{abstract}

Keywords: strategy, $4 C$ competence, PAI learning

How to Cite: Partono, Wardhani, H. N., Setyowati, N. I., Tsalitsa, A., \& Putri, S. N. (2021). Strategi meningkatkan kompetensi 4C (critical thinking, creativity, communication \& collaborative). Jurnal Penelitian Ilmu Pendidikan, 14(1), 41-52. doi:https://doi.org/10.21831/jpipfip.v14i1.35810.

Received 16-11-2020; Received in revised from 23-12-2020; Accepted 14-01-2021 


\section{PENDAHULUAN}

Pendidikan merupakan sebuah kegiatan yang sangat urgen dan berperan penting dalam menentukan perkembangan dan perwujudan dari individu, terutama bagi pembangunan bangsa dan negara. Karena pada hakikatnya suatu negara dikatakan memiliki kebudayaan yang maju salah satunya ditentukan dengan bagaimana budaya pendidikan di suatu negara itu diperankan, terutama dalam mengenali, menghargai dan mengembangkan kompetensi peserta didik agar ke depannya peserta didik menjadi sumber daya manusia yang berguna bagi masyarakat, bangsa dan Negara (Sari $\&$ Septiasari, 2016).

Setiap proses pendidikan tentunya memiliki tujuan, dan tujuan pendidikan nasional itu sendiri adalah mengembangkan potensi peserta didik agar menjadi manusia yang cerdas, beriman memiliki spiritualitas yang tinggi, dan bertakwa kepada Tuhan Yang Maha Esa, bertanggung jawab, cakap, aktif, kreatif, mandiri, dan menjadi warga negara yang toleran, demokratis serta berakhlak mulia. Oleh karena itu, setiap warga Negara Indonesia diwajibkan mengikuti program belajar yang diselenggarakan pemerintah pusat maupun pemerintah daerah. Hal ini termaktub dalam undangundang No. 20 tahun 2003 pasal 34 ayat 3, tentang wajib belajar bagi seluruh rakyat Indonesia (Sujatmoko, 2010).

Konsekuensi dari adanya UU tersebut ialah pendidikan saat ini diharapkan dapat mencetak peserta didik yang mampu mengikuti tantangan zaman, serta mampu bersaing di masa depan. Perubahan yang sangat cepat dan sulit pada berbagai aspek kehidupan dimasa depan ini bukan sebuah persoalan yang gampang. Perubahan yang sangat cepat tersebut sudah mulai berlangsung pada abad 21 ini. Sehingga abad 21 ini, disebut sebagai abad pengetahuan, abad ekonomi berbasis pengetahuan, abad globalisasi, abad teknologi informasi, abad yang dimana terjadi revolusi industri 4.0, dan sebagainya. Adapun perubahan yang terjadi sebenarnya dapat memberikan peluang jika dapat memanfaatkannya dengan baik, tetapi jika tidak dapat mengantisipasi secara sistematis, terstruktur, dan teratur maka perubahan tersebut justru akan menjadi sebuah masalah yang sangat besar.

Proliferasi komputer dan otomatisasi pencatatan di berbagai aspek kehidupan menjadi perubahan yang terjadi pada abad 21. Hal ini mengakibatkan pergerakan dunia industri dan persaingan kerja menjadi tidak linear. Salah satu karakteristik unik dari abad 21 ini adalah pengimplementasian kecerdasan buatan atau artificial intelligence (AI). Pengimplementasian aplikasi AI dalam kehidupan nyata dengan penggunaan robot untuk menggantikan tenaga manusia. Penggunaan robot dinilai lebih murah, efektif, dan efisien (Partono, 2020). Sehingga pada abad 21 ini banyak sekali sumber daya manusia yang sudah tergantikan dengan teknologi. Hal itu menyebabkan banyaknya sumber daya manusia yang tidak terpakai (menjadi pengangguran).

Guna mengantisipasi pengangguran yang semakin banyak, oleh karena itu pada abad 21 ini dibutuhkan sumber daya manusia yang memiliki ketrampilan yang memang tidak bisa dimiliki oleh robot (teknologi). Atau bahkan memiliki suatu keterampilan yang jauh lebih mumpuni dibandingkan robot. Adapun keterampilan-ketrampilan yang harus dimiliki tenaga kerja pada abad 21 yakni meliputi 4C (Critical Thinking, Communiaction, Collaborative, Creativity) (Redhana, 2019). Sehingga pada abad 21 sumberdaya manusia harus memiliki setidaknya 4 kompetensi guna mempersiapkan peserta didik agar mampu bersaing dalam dunia kerja yang serba berbasis teknologi.

Pendidikan abad 21 ini memiliki tanggung jawab yang tidak mudah, adapun salah satu tanggung jawab tersebut yakni mencetak output atau tenaga kerja yang berkualitas untuk memapu bersaing di abad 21 ini, dengan cara menerapkan atau membekali peserta didiknya dengan kompetensi 4C melalui program-program unggulan pada lembaga pendidikan yang ada di Indonesia. Akan tetapi melihat realita di lapangan masih banyak sekali lembaga pendidikan yang belum mampu mencetak output yang siap bersaing diabad 21 ini. Hal itu disebabkan oleh pelaksanaan pendidikan di Indonesia yang masih belum merujuk pada pembekalan 4C, melainkan masih berorientasi pada penguasaan materi saja. Yang mana goalnya pendidikan masih pada seberapa jauh peserta didik mampu menghafal materi, dan menjawab soal. Padahal tidak cukup menghadapi dunia kerja yang serba IT ini 
hanya dengan bekal materi pembelajaran. Sehingga pembekalan keterampilan softskill (4C) di era ini menjadi sangat mendesak.

Pembekalan softskill (keterampilan 4C) tidaklah mudah, sehingga perlu adanya sebuah strategi yang digunakan dalam rangka memudahkan seluruh lembaga pendidikan dalam membekali softskill kepada peserta didik. Adapun tanggung jawab pendidikan ini tidak hanya berlaku pada pendidikan yang ada di Indonesia saja. Melainkan juga pada lembaga pendidikan Indonesia yang ada di luar negeri seperti halnya Sekolah Indonesia Denhaag (SIDH). Yang sama-sama memiliki tanggung jawab mengembangkan softskill peserta didik. Sehingga tulisan ini akan membahas mengenai strategi yang digunakan SIDH dalam meningkatkan kompetensi 4C (Critical Thinking, Communication, Collaborative, Creativity) peserta didik. Oleh karena itu, adapun artikel ini bertujuan untuk memberikan wawasan mengenai strategi yang bisa digunakan oleh lembaga pendidikan baik di Indonesia ataupun SILN dalam mempersiapkan siswa-siswinya menjadi SDM yang mampu bersaing di dunia kerja abad 21 (era revolusi 4.0).

\section{METODE}

Jenis penelitian ini adalah penelitian deskriptif kualitatif, yaitu penelitian yang berisi penggambaran dari segala aspek penelitian yang dipaparkan secara jelas, akurat dan terperinci (Zed, 2014). Penelitian jenis ini menggunakan data-data dalam bentuk deskriptif antara lain berupa pernyataan fakta dari pelaku yang diamati yaitu Safreni Candra Sari dari Sekolah Indonesia Den Haag (Senior High School) dan Ponco Handayawati dari Sekolah Indonesia Den Haag (Junior High School). Penelitian dengan pendekatan ini dimaksudkan untuk mendapatkan data dan fakta langsung dari subjek yang terkait dan menjadikan fakta tersebut lebih mudah dipahami serta jika memungkinkan dapat menghasilkan temuan baru (Fitrah \& Luthfiyah, 2017). Dipilihnya metode kualitatif sebagai metode dalam penelitian ini yaitu karena peneliti ingin memperoleh data data terkait dengan strategi meningkatkan kompetensi 4C (Critical Thinking, Creativity, Communication, dan Collaborative). Penelitian ini dilakukan di Sekolah Indonesia Den Haag (SIDH), Belanda, dengan subjek penelitian siswa di SIDH.

Teknik pengumpulan data yang digunakan untuk menganalisis data yaitu melalui proses wawancara dengan menggunakan media aplikasi zoom. Selain menggunakan teknik wawancara, peneliti juga mendapatkan data melalui teknik dokumentasi. Dalam penelitian ini dokumen yang diperoleh adalah dokumen yang berbentuk gambar berupa slide PowerPoint yang berisi pemaparan materi terkait dengan kompetensi masa depan dan teknis pelaksanaan pembelajaran di Sekolah Indonesia Den Haag (SIDH).

\section{HASIL DAN PEMBAHASAN}

\section{Hasil}

Dalam mengasah 4 komponen kompetensi ini, SIDH (Sekolah Indonesia Den Haag) melatih peserta didik dengan menyampaikan ide gagasan, presentasi tugas, diskusi antar teman atau diskusi dengan tentor, serta pembelajaran dengan berbasis IT dengan bantuan guru dan orang tua bagi yang program PJJ (program jarak jauh).

\section{Kompetensi Critical Thinking}

Guru dalam kegiatan diskusi di kelas berperan sebagai pembimbing yakni memberikan motivasi dan bimbingan belajar supaya aktivitas diskusi siswa menjadi efektif.

Kompetensi critical thinking dapat dikembangkan melalui pembelajaran, seperti halnya di Sekolah Indonesia Den Haag (SIDH). Seluruh siswa di Sekolah Indonesia Den Haag (SIDH) mulai dari masuk ke jenjang Sekolah Dasar (SD), Sekolah Menengah Pertama (SMP) hingga Sekolah Menengah Atas (SMA) dibiasakan menggunakan metode diskusi dalam setiap pembelajaran di kelas.

Kegiatan diskusi biasa dilakukan di SIDH karena dianggap dapat meningkatkan kompetensi berpikir kritis siswa. Melalui diskusi, antar siswa dengan menggunakan pengalaman dan pengetahuannya akan saling bertukar pendapat untuk memecahkan dan menyelesaikan permasalahan 
yang sedang dihadapi.

\section{Kompetensi Creativity}

Ekstrakulikuler merupakan kegiatan sekolah di luar jam mata pelajaran wajib, yang disediakan oleh pihak sekolah. Siswa/siswi diberikan kesempatan memilih sendiri jenis ekstrakulikuler yang sesuai dengan masing masing bakat dan minatnya. Kebebasan memilih tersebut bertujuan supaya siswa dapat mengembangkan kemampuan melalui kegiatan ekstrakulikuler yang diikuti di sekolah. Adapun jenis kegiatannya pihak sekolah menyediakan dalam berbagai jenis bidang (Anggraini, Yuliasma, \& Iriani, 2018). Adapun kegiatannya bisa berupa budaya, sastra, dan bidang lainnya. Selain sebagai media pengembangan kemampuan, tujuan kegiatan ekstrakulikuler yakni untuk memperluas pengetahuan siswa di sekolah. Penyelenggaraan ekstrakurikuler dianggap penting ada di sekolah karena kegiatan ini dapat mengasah potensi, minat, dan bakat siswa. Ekstrakurikuler adalah seperangkat pengalaman belajar yang tentunya kegiatan ini juga mempunyai nilai manfaat dalam membentuk pribadi siswa yang kreatif (Partono \& Ashif Az Zafi, 2020). Salah satunya yaitu ekstrakurikuler tari.

Berdasarkan hasil wawancara yang dilakukan oleh peneliti, menari adalah salah satu kegiatan ekstrakulikuler yang ada di Sekolah Indonesia Den Haag (SIDH). Dari kegiatan ekstrakulikuler menari di Sekolah Indonesia Den Haag (SIDH) terbukti adanya peningkatan kompetensi kreativitas pada siswa. Hal ini sesuai dengan tujuan dari pihak sekolah yang ingin meningkatkan kompetensi masa depan pada diri siswa SIDH. Peningkatan kompetensi kreativitas siswa/siswi SIDH terlihat dari hasil wawancara dengan Ibu Ponco Handayawati (19 Agustus 2020), beliau mengungkapkan bahwa ada siswa SIDH yang menjadi duta budaya, menampilkan suatu tarian apabila terdapat penyelenggaraan acara seperti ulang tahun ASEAN ataupun lainnya. Keikutsertaan siswa SIDH dalam acara tersebut adalah sebagai perwakilan dari Kedutaan Besar Republik Indonesia (KBRI) Den Haag.

\section{Kompetensi Communication}

Di SIDH, program-program yang dapat dikaitkan untuk peningkatan kompetensi communication salah satunya adalah grup media sosial antara guru dan orang tua. Dalam sistem program ini, orang tua sangat antusias memantau proses pembelajaran peserta didik. Selain program grup media sosial masih banyak lagi program-program lain yang dapat meningkatkan kompetensi peserta didik. Mulai dari program kegiatan intrakurikuler maupun ekstrakulikuler. Pada program intrakurikuler peserta didik dikembangkan melalui materi pembelajaran di kelas baik kelas reguler ataupun kelas PJJ, seorang guru harus mampu meningkatkan ataupun membiasakan komunikasinya dengan peserta didik agar selalu berkembang melalui metode-metode yang di ajarkan.

Sama halnya dengan SIDH meskipun berdomisili di Belanda, SIDH juga masih tetap menjaga sistem pendidikan yang ada di Indonesia. Peningkatan keterampilan untuk menguasai 4C sudah berulang kali dikatakan sangat penting untuk kehidupan masa depan.

Keterampilan berkomunikasi menurut Canale \& Swan (1980) ialah keterampilan yang termasuk keterampilan mendengarkan, memperoleh informasi, dan menyampaikan gagasan di hadapan orang banyak. Berkomunikasi tujuannya mencapai pengertian bersama yang lebih baik mengenai masalah penting bagi semua pihak yang terkait. Keterampilan ini dapat dilatihkan di semua lembaga pendidikan maupun di lembaga lain dengan memberikan tantangan untuk menyampaikan gagasan kepada orang lain. Berkomunikasi dikatakan berhasil bila orang lain memahami atau sepakat dengan gagasan yang disampaikan.

Strategi yang sesuai untuk dilakukan guna meningkatkan komunikasi peserta didik yaitu adalah dalam proses pembelajaran guru harus membiasakan siswanya untuk saling berkomunikasi baik tentang pelajaran maupun hal lain, baik dengan guru maupun dengan siswa. Bahasa yang digunakan siswa dalam berkomunikasi akan memberikan dampak pada siswa itu sendiri. Penggunaan kata yang tidak baik dalam komunikasi membawa dampak negatif. Pesan yang disampaikan oleh siswa tidak dapat diterima oleh penerima pesan. Hal ini akan memicu terjadinya kesalahan dalam penerimaan pesan yang dapat menimbulkan kesalahpahaman atau konflik dalam berinteraksi. Selain itu, membiarkan peserta didik menggunakan kata-kata kasar dalam berkomunikasi dapat menimbulkan kebiasaan buruk bagi mereka. Penggunaan kata yang baik dalam berkomunikasi akan membawa dampak positif pada peserta didik (Septikasari \& Frasandy, 2018). Seiringnya 
perkembangan zaman, kita tentunya perlu tahu bagaimana cara berkomunikasi secara efektif. Komunikasi efektif yaitu komunikasi yang mampu menghasilkan perubahan sikap (attitude change) pada orang lain yang bisa terlihat dalam proses komunikasi. Komunikasi efektif dapat melatih penggunaan bahasa nonverbal secara baik.

\section{Kompetensi Collaborative}

Di setiap lembaga pendidikan pastilah memiliki program-program tertentu yang berguna untuk meningkatkan keterampilan setiap peserta didik. Seperti halnya di Sekolah Indonesia Den Haag atau SIDH sebagai salah satu sekolah yang terdaftar ke dalam Sekolah Indonesia Luar Negeri atau SILN dari beberapa negara lainnya.

Lembaga pendidikan SIDH menyelenggarakan dua sistem pendidikan yaitu pendidikan reguler dan pendidikan jarak jauh (PJJ). Adapun tujuan dari PJJ adalah memberikan layanan pendidikan kepada putra-putri masyarakat Indonesia yang sedang bermukim sementara di Belanda dan Eropa yang karena keterbatasan geografis tidak bisa mengikuti pembelajaran tatap muka dan reguler di SIDH. Layanan PJJ ini, berlaku untuk semua jenjang di SIDH, mulai dari SD, SMP, dan SMA. Dalam sistem pendidikan PJJ dilaksanakan melalui program Rumah Belajar.

Program Rumah Belajar dipilih sebagai sistem pendidikan PJJ karena penggunaan internet di dunia sudah sangat meluas dan hampir seluruh kegiatan tidak lepas dari yang namanya dunia internet. Sama halnya seperti dalam dunia pendidikan baik di SIDH ataupun di lembaga pendidikan lain baik dalam negeri ataupun luar negeri. Hal inilah yang memungkinkan proses pembelajaran berlangsung secara daring melalui sebuah portal khusus berbasis web http://belajar.kemedikbud.go.id yang resmi dimiliki kementerian pendidikan dan kebudayaan. Kementrian Pendidikan Nasional membangun portal Rumah Belajar ini tidak lepas dari dinamika dunia pendidikan yang menuntut pengembangan media pembelajaran yang multiakses, cepat, berbiaya murah, serta mampu menghubungkan banyak orang. Untuk itulah, pembangunan portal Rumah Belajar dirancang dengan sejumlah kelebihan yaitu pertama, menyediakan fasilitas belajar baik bagi siswa maupun bagi guru. Kedua, memiliki berbagai media pembelajaran multimedia berupa: teks, grafis, foto, video, audio, dan animasi. Ketiga, menyediakan kumpulan soal yang lengkap baik untuk latihan maupun try out ujian. Keempat, guru dapat memodifikasi dan mereproduksi rancangan pembelajaran dan materi pembelajaran. Kelima, siswa dapat mengembangkan jaringan komunikasi dan kreatif (Hakim, 2016; Warsita, 2019).

SIDH berkolaborasi dengan Pusdatin dalam pelaksanaan program Rumah Belajar. Kolaborasi menjadi salah satu faktor pendukung yang sangat penting dalam pendidikan di SIDH baik pendidikan secara reguler maupun secara PJJ. Kolaborasi tersebut sangat didukung agar SIDH tetap terhubung bukan hanya dengan para siswa di Belanda saja namun juga dengan para siswa di Indonesia.

Rumah belajar sangat membantu dan memudahkan guru untuk membuat pembelajaran menjadi lebih menarik karena tersedia berbagai komponen yang diperlukan untuk pembelajaran, baik di kelas maupun di luar kelas, terutama penugasan kepada peserta didik agar peserta didik sedini mungkin mengenal teknologi.

Fitur sumber belajar pada portal Rumah Belajar menyediakan berbagai konten pembelajaran digital, baik konten yang sesuai kurikulum maupun materi pengayaan. Semua fitur Portal Rumah Belajar tersebut dapat dijadikan sebagai sumber belajar untuk peserta didik PAUD, SD/MI, SMP/MTs, SMA/MA, dan SMK. Selain itu, bahan belajar ini dapat diunduh (download) dan digunakan sesuai kebutuhan belajar. Dengan memanfaatkan sumber belajar pada Portal Rumah Belajar ini peserta didik dituntut untuk aktif dalam menyimpulkan, menganalisis, dan mengurutkan fungsi serta kelainan pada sistem gerak pada manusia (Nurhayati, Utari, Mutmainah, Hamidi, \& Warsita, 2019). Fitur-fitur yang terdapat dalam portal Rumah Belajar antara lain yaitu, pertama, sumber belajar. Fitur sumber belajar adalah salah satu layanan fitur yang tersedia di dalam Rumah Belajar, layanan fitur sumber belajar diperuntukkan untuk memenuhi kebutuhan belajar siswa di sekolah. Sumber belajar memiliki fungsi yang strategis dalam pembelajaran, yaitu: a) meningkatkan produktivitas pembelajaran, b) memberikan kemungkinan pembelajaran yang sifatnya lebih individual, c) memberikan dasar yang lebih ilmiah terhadap pembelajaran, dan sebagainya.

Kedua, BSE (Buku Sekolah Elektronik). BSE adalah inisiatif dari kementerian pendidikan dan kebudayaan Indonesia bertujuan untuk menyediakan buku ajar elektronik. Ketiga, Lab Maya. Laboratorium virtual merupakan bentuk tiruan dari sebuah laboratorium riil yang digunakan dalam 
aktivitas pembelajaran ataupun penelitian secara ilmiah guna menekankan sebuah konsep atau mendalami sebuah konsep-konsep tertentu.

Keempat, Peta Budaya. Layanan fitur peta budaya tersebut diperuntukkan untuk memenuhi kebutuhan belajar siswa dan guru di sekolah maupun masyarakat yang ingin mengetahui keanekaragaman budaya Indonesia. Kelima, Bank Soal. Fitur Bank Soal dikembangkan sebagai wadah bagi guru-guru untuk membuat soal dan berbagi kepada pengguna yang lain, serta melakukan evaluasi hasil belajar secara online. Keenam, Wahana Jelajah Angkasa. Fitur Wahana Jelajah Angkasa adalah tur virtual dengan medan turnya adalah luar angkasa. Fitur Wahana Jelajah Angkasa memanfaatkan program Worldwide Telescope (WWT) dengan bahasa pengoperasian utamanya disajikan dalam Bahasa Inggris. Kegiatan tur virtual ini dilakukan secara real-time. Ketujuh, PKB (Pengembangan Keprofesian Berkelanjutan). Fitur PKB dikembangkan sebagai wadah bagi penyelenggara diklat untuk memberikan layanan peningkatan kualitas SDM, dalam bentuk diklat secara online (Kemendikbud).

SIDH selain berkolaborasi dengan Rumah belajar, juga berkolaborasi dengan sekolah lokal yang ada di Belanda yaitu Stedelijk Collage. Kerjasama yang dilakukan antara SIDH dengan sekolah lokal Belanda yaitu dengan saling memperkenalkan budaya masing-masing. Peserta didik SIDH memperkenalkan budaya Indonesia. SIDH juga tetap selalu menjaga kebudayaan Indonesia yaitu salah satunya dengan memperingati hari guru namun tetap menggunakan budaya Indonesia yaitu menggunakan nasi tumpeng.

\section{Peningkatan Kompetensi 4C melalui Praktik Pembelajaran PAI}

Adapun dari pengamatan yang dilakukan oleh peneliti mengenai bagaimana praktik pembelajaran PAI di Sekolah Indonesia Den Haag (SIDH), ditemukan adanya tantangan yang harus dihadapi oleh guru maupun siswa SIDH. Temuan tersebut berdasar pada hasil wawancara dengan Ibu Safreni Candra Sari (19 Agustus 2020).

Tantangan yang harus dihadapi berkaitan dengan pemahaman makanan halal dan haram. Upaya memahamkan siswa/siswi mengenai halal haramnya jenis makanan, menjadi tantangan terbesar bagi para guru. Alasannya adalah karena tinggal di negara yang hampir semua makanannya terdapat kandungan babi. Makanan yang dijual yang berbahan dasar daging pun lebih banyak menggunakan daging babi. Apabila ada yang menjual daging sapi tetap saja daging sapi tersebut kebanyakan tidak disembelih dengan menyebut nama Allah. Sedangkan menurut agama Islam jenis jenis makanan tersebut hukumnya haram dimakan.

Meskipun demikian karena memperoleh banyak pengetahuan dari teman sesama muslim serta para ustaz/ustazah yang ada di Belanda, guru-guru di SIDH khususnya guru PAI selalu mengingatkan siswa/siswinya untuk memilih makanan yang halal. Selain itu di SIDH siswa selalu saling mengingatkan satu sama lain. Bahkan siswa seringkali membawa bekal makan siang dari rumah sehingga terjamin kehalalan makanannya.

Hal demikian menjadi suatu tugas yang harus dikerjakan seorang guru PAI dalam memberikan suatu pemahaman untuk dapat memilih makanan dan minuman yang halal sesuai dengan hukum agama Islam. Dalam meningkatkan pembelajaran PAI seorang guru harus memiliki strategi sendiri untuk menciptakan suasana belajar yang kondusif, aktif, dan kreatif guna untuk dapat menyampaikan materi kepada peserta didik dengan mudah dan dapat diterima.

Pembelajaran PAI di Sekolah Indonesia Den Haag dilakukan dengan strategi tertentu yang dapat meningkatkan kompetensi 4C. Strategi yang digunakan disesuaikan dengan tujuan dan materi pembelajaran yang sebelumnya telah ditentukan serta karakteristik siswa dilihat dari segi daya tangkap siswa. Hal tersebut sesuai dengan hasil wawancara peneliti dengan Ibu Safreni Candra Sari selaku Wali Jenjang SMA:

"Teorinya sama dengan di Indonesia. Guru PAI menggunakan buku-buku Indonesia, memasukkan beberapa kasus, apa yang terjadi di Belanda. Sehingga dalam praktiknya, apa yang bisa dipraktikkan seperti berwudhu, sekolah menyediakan keran-keran (tempat berwudhu) dengan air hangat. Sekolah ikut berpartisipasi dalam mensukseskan praktik ibadah dengan menyediakan mushola yang nyaman." (Sari, wawancara, 19 Agustus 2020)

Dari hasil wawancara dengan Wali Jenjang SMA Ibu Safreni tersebut, menggambarkan bahwa dari guru bidang pendidikan agama Islam dalam proses pembelajarannya menggunakan buku- 
buku pelajaran sama dengan yang digunakan di Indonesia, sehingga teori-teori yang disampaikan sesuai dengan yang ada di dalam buku pelajaran, dengan disertai memasukkan beberapa kasus yang terjadi di Belanda. Strategi yang digunakan oleh guru untuk materi PAI yang bersifat praktik seperti praktik berwudhu adalah dengan melaksanakan kegiatan belajar mengajar yang inovatif. Dalam proses pembelajarannya guru tidak hanya menyampaikan materi kepada siswa secara lisan tentang tata cara melaksanakan rukun wudhu, sunah wudhu, gerakan wudhu, dan sebagainya, akan tetapi guru juga memberikan bekal pengetahuan, mengaitkan antara materi wudhu dengan situasi dan kondisi di Belanda serta memperagakan gerakan-gerakan wudhu pada siswa.

Bekal pengetahuan yang diberikan oleh guru, misal pada saat musim dingin suhu akan terasa lebih dingin sehingga siswa tidak mungkin berwudhu dengan menggunakan air yang dingin pula. Oleh karena itu dalam hal tersebut guru pun memberikan bekal pengetahuan kepada siswa mengenai opsi atau pilihan apa yang dimiliki agar siswa tetap dapat berwudhu. Opsi yang dimiliki berupa siswa dapat berwudhu dengan menggunakan air hangat. Strategi-strategi tersebut digunakan oleh guru PAI untuk meningkatkan kompetensi 4C dalam diri siswa.

Dari penjelasan di atas dapat dilihat bahwa ternyata melalui praktik pembelajaran PAI, kompetensi 4C yang dimiliki siswa SIDH juga dapat berkembang. Perkembangan kompetensi 4C terletak pada strategi yang digunakan oleh guru PAI dengan melaksanakan kegiatan belajar mengajar yang inovatif.

\section{Pembahasan}

Perkembangan tatanan global membuat persaingan dalam dunia kerja semakin ketat. Kompetensi 4C diperlukan untuk menyelesaikan tugas-tugas yang seharusnya dilakukan oleh manusia tetapi tergantikan oleh robot. Kompetensi $4 \mathrm{C}$ yang telah dilakukan oleh pengajar dan para siswa di SIDH mencakup cara berfikir kritis, mengembangkan kreativitas, meningkatkan kompetensi berkomunikasi dan pengembangan kolaborasi. Pelatihan berfikir kritis yang dilakukan di SIDH dengan memberikan contoh permasalahan dan berdiskusi mencari solusi untuk masalah tersebut. Sehingga nanti dalam kehidupan sehari-hari peserta didik akan terbiasa berpikir secara sistematis dalam memecahkan masalah. Critical thinking atau berpikir kritis merupakan salah satu kompetensi yang harus dimiliki oleh peserta didik di abad 21. Berpikir kritis ini sangat diperlukan dalam kehidupan untuk menganalisis suatu masalah dan menemukan solusi untuk masalah yang muncul di era sekarang dan kedepannya. Berpikir kritis menurut John Dewey adalah pertimbangan yang aktif, terus menerus dan teliti mengenai sebuah keyakinan atau bentuk pengetahuan yang diterima begitu saja dengan menyertakan alasan-alasan yang mendukung dan kesimpulan-kesimpulan yang rasional (Rachmadtullah, 2015). Berpikir kritis merupakan suatu konsep pemecahan suatu masalah dengan menganalisis secara mendalam untuk mendapatkan solusi dari masalah yang terjadi.

Metode diskusi yang digunakan dalam kegiatan belajar mengajar merupakan salah satu metode yang dapat meningkatkan kompetensi critical thinking siswa, seperti Syah yang menggambarkan kemampuan berpikir kritis sebagai wujud dari perilaku belajar yang berhubungan dengan penyelesaian masalah. Maksud dari pendapat Syah adalah seseorang akan berpikir kritis setelah ia menemukan suatu persoalan. Dalam kegiatan diskusi siswa secara pribadi ataupun kelompok akan bertukar pendapat untuk menemukan solusi atau membuat kesimpulan mengenai suatu materi yang telah ditentukan oleh guru (Bahri \& Supahar, 2019). Dengan berdiskusi siswa memperoleh motivasi untuk memecahkan persoalan dengan menggunakan pengalaman dan pengetahuan yang dimilikinya. Dengan kata lain siswa tidak bergantung pada pendapat-pendapat yang dikemukakan oleh siswa lain. Selain itu, siswa mampu mengungkapkan pendapatnya dengan lisan secara langsung. Dengan demikian siswa melatih diri hingga dapat membiasakan diri untuk selalu mengungkapkan pendapatnya (Ahmad, Tambak, \& Siwal, 2018).

Peserta didik selain harus memiliki kemampuan berfikir kritis, juga harus mengembangkan kreativitasnya. NACCCE (National Advisory Committee on Creative and Culture Education) menyampaikan bahwa kreativitas sebagai aktivitas imaginatif yang menghasilkan karya yang baru dan bernilai (Fakhriyani, 2016). Kreativitas juga sebagai sebuah proses untuk peka terhadap masalah, menyadari adanya kelemahan atau kekurangan, menyadari adanya gap dalam pengetahuan, juga menyadari apabila ada elemen-elemen yang salah, adanya ketidakharmonisan, dapat mengidentifikasi kesulitan, dapat mencari solusi, serta dapat membuat pertanyaan-pertanyaan atau memformulasikan 
hipotesis tentang sebuah kekurangan melalui serangkaian tes dan retes yang dimodifikasi dan hasilnya dapat dikomunikasikan (Asmawati, 2017).

Kreativitas peserta didik mencakup kreativitas aptitude dan non-aptitude. Guilford (Fakhriyani, 2016) berpendapat, aptitude berhubungan dengan kognisi atau proses berfikir. Aptitude membutuhkan kelancaran dalam menghasilkan suatu keputusan secara cepat (fluency), dapat menggunakan berbagai cara untuk mengatasi sebuah masalah (flexibility), juga berkemampuan untuk membuat gagasan yang asli (originality), dan membutuhkan kemampuan untuk melakukan sesuai dengan detail agar suatu objek menjadi lebih menarik (elaboration). Sedangkan non-aptitude berhubungan dengan sikap atau perasaan, motivasi atau dorongan dari dalam diri untuk berbuat sesuatu. Non-aptitude merupakan segala sesuatu yang berhubungan dengan perasaan ataupun motivasi misalnya imajinasi yang kuat, inisiatif, kebebasan berpikir, selalu ingin tahu, dan lain-lain.

Keterampilan komunikasi adalah bagian dari keterampilan abad 21 yang harus dimiliki oleh peserta didik. Karena komunikasi merupakan alat interaksi untuk menciptakan hubungan antar individu sebagai implementasi dari kodrat manusia sebagai makhluk sosial. Komunikasi merupakan proses individu yang kaitannya dengan, kelompok, organisasi, dan masyarakat yang membuat dan menggunakan informasi untuk berhubungan satu sama lain dengan lingkungan. Komunikasi juga diartikan sebagai sarana dalam menyampaikan pesan, mengekspresikan diri, serta mempengaruhi orang lain.

Keterampilan komunikasi memiliki fungsi yang sangat urgen dalam membekali siswa menghadapi dan bersaing di dunia kerja, karena selain berfungsi sosial, komunikasi juga berfungsi pengambilan. Komunikasi dalam fungsi sosial, menurut Verderber \& Gorden (Marfuah, 2017) berperan sebagai alat yang digunakan oleh peserta didik untuk membangun dan memelihara hubungan dengan orang lain. Sedangkan komunikasi dalam fungsi pengambilan, merupakan fungsi yang digunakan peserta didik untuk mengambil keputusan yang dilakukan dalam menyelesaikan sebuah permasalahan. Adapun komunikasi dalam konteks pendidikan diartikan sebagai keterampilan yang harus dimiliki dan dikuasai oleh seorang peserta didik karena keterampilan ini sangat berguna untuk menggali pengetahuan sebanyak-banyaknya serta untuk menyampaikan informasi kepada orang lain baik secara lisan maupun tulisan (Marfuah, 2017).

Komponen-kompetensi komunikasi yang harus dikuasai oleh peserta didik secara teori, minimal mencakup empat komponen, sebagaimana yang dikemukakan oleh Canale \& Swain (Beale, 2002). Pertama, komponen gramatikal, yang mana komponen gramatikal yakni kompetensi yang berkaitan dengan penguasaan kaidah kebahasaan, baik verbal maupun non-verbal seperti halnya ilmu bunyi (pelafalan), kosakata, penulisan, pembentukan kata, dan pembentukan kalimat. Kompetensi kebahasaan atau kompetensi komunikasi adalah pengetahuan berkaitan tentang tata bahasa serta kemampuan dalam menggunakannya saat berkomunikasi (Chomsky, 1965). Namun menurut Savignon (1983) penekanan bahasa bukan pada seberapa jauh pengetahuan peserta didik tentang kaidah bahasa tersebut melainkan pada pemakaian kaidah tersebut, sehingga dengan demikian, kompetensi komunikatif pelajar diukur dengan kemampuannya membuat ungkapan yang benar sesuai dengan kaidah, bukan terletak pada kemampuannya menghafal kaidah.

Kedua, komponen sosiolinguistik, komponen sosiolinguistik yakni penguasaan aturan penggunaan bahasa dalam konteks sosio-kultural. Oleh karena itu, pada komponen ini diperlukan pemahaman terhadap faktor-faktor tertentu, seperti halnya: peran dan status lawan komunikasi, tujuan dan fungsi dari interaksi dan komunikasi, etika dan norma interaksi dan sebagainya. Jadi, kemampuan sosiolinguistik ini adalah salah satu kompetensi antar disiplin ilmu di mana peserta didik bisa menggunakan bahasa secara baik dan wajar dalam konteks sosial kultural. Komponen sosiolinguistik dapat diartikan sebagai, ekspresi dan pemahaman makna-makna sosial yang tepat serta maksimal yakni mencakup fungsi, sikap dan topik komunikasi dalam konteks sosiolinguistik yang beraneka ragam; Ekspresi dan pemahaman bentuk-bentuk gramatikal yang tepat serta maksimal yang berkaitan dengan fungsi komunikatif yang beraneka ragam dalam konteks sosiolinguistik. Sehingga dapat disimpulkan bahwasannya komponen sosiolinguistik adalah komponen komunikasi yang berkaitan tentang etika dan norma dalam berinteraksi dan berkomunikasi sesuai dengan etika dan norma yang berkembang.

Ketiga, komponen wacana yakni kemampuan peserta didik untuk memberikan penafsiran mengenai topik paragraf, bab atau buku dengan memperhatikan keterpaduan struktur, keterkaitan, dan 
keutuhan makna satu dengan makna yang lain. Kompetensi wacana yakni kemampuan peserta didik dalam menafsirkan serangkaian kalimat atau ungkapan dalam rangka mempertahankan keutuhan makna dan keterpaduan teks sesuai dengan konteksnya.

Keempat, komponen strategis, kompetensi strategis yaitu kemampuan untuk memperjelas efektifitas komunikasi dan mengimbangi kemampuan komunikasi antar sesama, atau dapat dikatakan kompetensi ini merupakan salah satu komponen pelengkap dalam komunikasi. Menurut Huda, kompetensi strategis ialah kemampuan penguasaan strategi komunikasi verbal dan nonverbal, dalam rangka mengatasi kejumudan komunikasi karena keterbatasan kosa kata, dan gramatikal, serta meningkatkan efektifitas komunikasi.

Karakteristik kompetensi komunikatif mencakup pengetahuan dan kemampuan penggunaan verbal dalam berbagai konteks atau situasi saat berkomunikasi. Savignon (1972) menyatakan karakteristik kompetensi komunikatif meliputi kompetensi komunikatif yang bersifat dinamis. Bersifat dinamis karena tergantung pada kesepakatan dalam memaknai kata antara dua belah pihak yang berkomunikasi atau lebih yang sama-sama mengerti kaidah pemakaian bahasa. Dalam konteks ini kemampuan komunikasi dapat dikatakan bersifat interpersonal. Kompetensi komunikatif meliputi penggunaan bahasa, baik secara tertulis maupun lisan.

Selain bersifat dinamis, kompetensi komunikatif juga bersifat kontekstual yakni komunikasi selalu terjadi pada situasi dan kondisi tertentu. Sehingga keberhasilan komunikasi tergantung pada pengetahuan partisipan terhadap topik yang dibicarakan. Kompetensi komunikasi berkaitan dengan pembagian kompetensi dan performansi, yang mana kompetensi berkaitan dengan apa yang diketahui peserta didik, sedangkan performansi berkaitan pada apa yang dilakukan. Sehingga pada konteks ini performansi saja yang dapat diamati, dikembangkan, dipertahankan dan dievaluasi. Kompetensi komunikatif bersifat relatif, tidak absolut.

Sejumlah karakteristik kompetensi komunikatif dapat digunakan untuk melihat apakah suatu bentuk perkataan bersifat komunikatif atau tidak. Yang mana kompentesi komunikatif tidak hanya memperhatikan masalah kegramatikalan saja, melainkan juga memperhatikan kesesuaian dengan faktor sosial dan kultural. Karena pada hakikatnyanya kompetensi komunikatif mencakup dua hal yaitu pengetahuan tentang kaidah kebahasaan, dan penggunaan bahasa (praktik) (Astriani, 2018). Pengasahan kompetensi komunikasi peserta didik tidak cukup jika dilakukan berdasarkan satu cara saja. Yakni melalui pembelajaran bahasa saja, ataupun kegiatan praktik saja. Kompetensi komunikasi peserta didik bisa dibentuk dengan cara Learning to Know, learning to do. Peserta didik tahu bagaimana cara berkomunikasi yang baik dan benar serta diasah melalui pembelajaran yang mendukung seperti halnya menyampaikan ide gagasan, presentasi tugas, diskusi.

Kompetensi lain yang tidak kalah urgen yang harus dimiliki seorang pendidik dalam rangka menyiapkan diri menghadapi revolusi industri 4.0 atau abad 21 adalah kompetensi kolaborasi.

Kolaborasi bukanlah sesuatu yang instan, diperlukan penanaman dan penerapan dalam diri setiap peserta didik, seorang dikatakan memiliki kemampuan berkolaborasi, bila memenuhi tiga komponen kemampuan berkolaborasi yaitu: menunjukkan kemampuan bekerja secara efektif dan menghargai keberagaman anggota tim; menunjukan fleksibilitas dan kemauan untuk menerima pendapat orang lain dalam mencapai tujuan bersama, dan dapat mengemban tanggung jawab bersama dalam bekerja kolaboratif dan menghargai kontribusi setiap anggota tim (Trailing \& Fadel, 2009). Kompetensi kolaborasi yakni kompetensi atau kemampuan peserta didik dalam bekerja sama, saling bersinergi dengan teman sebaya atau bertanggung jawab dengan masyarakat dan lingkungannya. Dengan demikian peserta didik akan senantiasa berguna bagi lingkungannya. Kompetensi kolaborasi juga diartikan sebagai kemampuan peserta didik dalam berkomunikasi dan berkerja sama secara efektif dan efisien dengan pihak lain. Kompetensi kolaborasi peserta didik ini sudah terindifikasi sebagai sebuah ketrampilan yang sangat penting sebagai hasil pendidikan (Sugiyarti, Arif, \& Mursalin, 2018).

NRC menjabarkan beberapa anggapan tentang status kompetensi kolaborasi sebagai kompetensi yang sangat penting di masa depan. Pertama, kompetensi kolaborasi memiliki efek yang berpengaruh pada proses belajar siswa, dan retensi pengetahuan, kompetensi kolaborasi diyakini memiliki keunggulan yang berbeda dibanding penyelesaian persoalan secara mandiri karena dengan berkolaborasi memungkinkan untuk pembagian kerja secara efektif, penggabungan informasi dari berbagai sumber pengetahuan, pengalaman, dan perspektif, adanya peningkatan kreatifitas karena 
adanya ide-ide dari anggota kelompok, selain itu kompetensi kolaborasi juga meningkatkan rasa peduli peserta didik terhadap sesama.

Kedua, dengan kompetensi kolaborasi peserta didik dapat meningkatkan penerapan pengetahuan, keterampilan pemecahan masalah, dan pengaturan sosial. Dengan kompetensi kolaborasi juga peserta didik dapat menggabungkan potensi dan keahlian peserta didik untuk dapat berinovasi. Sehingga kompetensi kolaborasi menjadi kompetensi yang sangat penting bagi peserta didik dalam menghadapi dunia kerja untuk ke depannya (Simarmata dkk., 2020). Karena sehebat apapun seseorang jika tidak terbiasa bekerjasama dengan orang lain maka tidak akan berhasil mencapai tujuan yang telah ditentukan. Oleh karena, itu pada abad 21 ini kompetensi kolaborasi menjadi kompetensi yang sangat urgen untuk mencapai kesuksesan.

Keterampilan kolaboratif dapat dilatihkan melalui strategi cooperative learning. Dalam pembelajaran kooperatif dibelajarkan untuk berkolaborasi. Slavin (1995) menyatakan pembelajaran kooperatif, memiliki banyak bentuk (tipe), tetapi semuanya melibatkan siswa bekerja dalam kelompok kecil atau tim yang saling membantu satu sama lain dalam mempelajari materi pelajaran. Dalam strategi pembelajaran kooperatif dapat ditemukan pendidikan nilai moral yaitu: terdapat penghargaan terhadap kelompok, tanggung jawab perseorangan dan kelompok, kesempatan untuk berhasil bersama, belajar menyenangkan, bekerja berpasangan, dan bekerja kelompok (Arnyana, 2019).

Kompetensi yang dimiliki seseorang tidaklah bersifat instan dan otomatis melainkan membutuhkan sebuah proses untuk membentuk dan meningkatan kompetensi tersebut. Begitu juga kompetensi kolaborasi, membutuhkan waktu yang tidak singkat untuk membekali kompetensi kolaborasi pada peserta didik. Adapun upaya SIDH dalam meningkatkan kompetensi kolaborasi yakni melalui strategi cooperative learning, karena strategi cooperatif learning terdapat nilai moral yang dapat diambil peserta didik. Penghargaan terhadap kelompok, tanggung jawab kelompok, kesempatan berhasil bersama, bekerja kelompok. Strategi kooperatif dipilih karena penggunaan strategi ini dinilai dapat menumbuhkan keterampilan kolaborasi serta memunculkan nilai moral melalui pembelajaran kooperatif.

\section{PENUTUP}

Kompetensi 4C terdiri dari kompetensi berpikir kritis (critical thinking), kompetensi kreativitas (creativity), kompetnsi komunikasi (communication), dan kompetensi kolaborasi (collaborative). Meningkatkan kompetensi 4C sangat diperlukan untuk persiapan pada masa depan. SIDH (Sekolah Indonesia Den Haag) memiliki berbagai strategi dalam meningkatkan kompetensi 4C tersebut. Strategi dalam meningkatkan kompetensi berpikir kritis (critical thinking) yaitu dengan melatih siswa untuk berdiskusi sejak dari jenjang SD hingga SMA. Dalam meningkatkan kompetensi kreativitas (creativity) salah satunya melalui ektrakulikuler yang disediakan oleh SIDH. Meningkatkan kompetensi komunikasi (communication) dapat melalui proses pembelajaran dengan memberikan kebebasan kepada siswa untuk berpendapat. Sedangkan strategi dalam meningkatkan kompetensi kolaborasi (collaborative) yaitu SIDH bekerjasama dengan pusdatin. Meningkatkan strategi 4C ini juga dapat melalui pembelajaran PAI. Strategi yang digunakan oleh guru PAI untuk materi yang bersifat praktik adalah dengan melaksanakan kegiatan belajar mengajar yang inovatif. Guru tidak hanya menyampaikan materi pembelajaran bidang PAI secara lisan, akan tetapi guru juga memberikan bekal pengetahuan, mengaitkan antara materi dengan situasi dan kondisi di Belanda serta memperagakan materi pembelajaran yang akan dipraktikkan.

\section{UCAPAN TERIMA KASIH}

Peneliti mengucapkan terima kasih kepada Sekolah Indonesia Den Haag terutama Ibu Safreni Candra Sari (Senior High School) dan Ibu Ponco Handayani (Junior High School) selaku narasumber.

\section{DAFTAR PUSTAKA}

Ahmad, M., Tambak, S., \& Siwal. (2018). Penerapan metode diskusi dalam meningkatkan hasil belajar murid pada pelajaran fiqh. Jurnal Al-Hikmah, 15(01), 65. https://doi.org/10.25299/jaip.2018.vol15(1).1585. 
Anggraini, F., Yuliasma, \& Iriani, Z. (2018). Upaya guru dalam meningkatkan kreativitas siswa dalam ekstrakulikuler seni tari di smp negeri 15 Padang. E-Jurnal Sendratasik, 6(2), 65. http://ejournal.unp.ac.id/index.php/sendratasik/article/view/100239.

Arnyana, I. B. P. (2019). Pembelajaran untuk meningkatkan kompetensi 4c era abad 21. Prosiding: Konferensi Nasional Matematika dan IPA, Universitas PGRI Banyuwangi. https://ejournal.unibabwi.ac.id/index.php/knmipa/article/view/829.

Asmawati, L. (2017). Peningkatan kreativitas anak usia dini melalui pembelajaran terpadu berbasis kecerdasan jamak. Jurnal Pendidikan Usia Dini, 11(1), 148. https://doi.org/10.21009/JPUD.111.

Astriani, E. (2018). Kompetensi komunikatif. Jurnal Ilmiah Pendidikan Bahasa dan Sastra Indonesia, 4(2), 3-5. e-jurnal.unisda.ac.id/index.php/pentas/article.

Bahri, M. F., \& Supahar. (2019). Kemampuan berpikir kritis menggunakan tes terintegrasi agama dan sains dalam pembelajaran pai di sma. Edukasi Islami: Jurnal Pendidikan Islami, 08(02), 240. doi:http://dx.doi.org/10.30868/ei.v8i2.402.

Beale, J. (2002). Is communicative language teaching a thing of the past? Babel, 37(1), 3. doi: https://www.academia.edu/2370003/Is_communicative_language_teaching_a_thing_of_the_p ast.

Canale, M., \& Swain, M. (1980). Theorical bases of communicative aproaches to second language teaching and testing. Applied Linguistics, $1(1), 30 . \quad$ doi: https://www.researchgate.net/profile/Merrill-

Swain/publication/31260438_Theoretical_Bases_of_Communicative_Approaches_to_Second _Language_Teaching_and_Testing/links/0c960516b1dadad753000000/Theoretical-Bases-ofCommunicative-Approaches-to-Second-Language-Teaching-and-Testing.pdf.

Chomsky, N. (1965). Aspects of the theory of syntax. Cambridge: The M.I.T. Press

Fakhriyani, D. V. (2016). Pengembangan kreativitas anaka usia dini. Wacana Didaktika Jurnal Pemikiran Penelitian Pendidikan dan Sains, 4(2), 194. http://doi.org/10.31102/wacanadidaktika.4.2.193-200.

Fitrah, M., \& Luthfiyah. (2017). Metodologi penelitian: Penelitian kualitatif, tindakan kelas \& studi kasus. Bandung: CV Jejak.

Hakim, W. (2016). Pengaruh penerimaan teknologi dengan kebergunaan web. Jurnal: Ultimaccom, $8(1)$, http://download.garuda.ristekdikti.go.id/article.php?article=940965\&val=14592\&title.

Marfuah. (2017). Meningkatkan keterampilan komunikasi peserta didik melalui model pembelajaran kooperatif tipe jigsaw. Jurnal Pendidikan Ilmu Sosial, 26(2), 151. ejournal.upi.edu.

Nurhayati, A. S., Utari, I., Mutmainah, S., Hamidi, J., \& Warsita, B. (2019). Pedoman pemanfaatan portal rumah belajar. Banten: Kemendikbud. http://simpatik.belajar.kemdikbud.go.id/uploads.

Partono. (2020). Pendidikan akhlak remaja keluarga muslim di era industri 4.0. Jurnal Dirasah. 3(1), 80. https://ejournal.iaifa.ac.id/index.php/dirasah.

Partono \& Az Zafi, A. (2020). Penguatan pendidikan karakter melalui ekstrakurikuler keislaman. Jurnal Inteligensia, 8(1), 9-10. https://osf.io/sxfbd/download.

Rachmadtullah, R. (2015). Kemampuan berpikir kritis dan konsep diri dengan hasil belajar pendidikan kewarganegaraan siswa kelas v sekolah dasar. Jurnal Pendidikan Dasar, 6(2), 289. http://pps.unj.ac.id/journal/jpd/article/view.

Redhana, I. W. (2019). Mengembangkan keterampilan abad ke-21 dalam pembelajaran kimia. Jurnal Inovasi Pendidikan Kimia, 13(1), 2239-2240. https://journal.unnes.ac.id>article>view.

Sari, Z. O., \& Septiasari, E. A. (2016). Pentingnya kreativitas dan komunikasi pada pendidikan jasmani dan dunia olahraga. Jurnal: Olahraga Prestasi, $12(1), 99$. https://journal.uny.ac.id/index.php/jorpres/article/download/9500.

Savignon, S. J. (1972). Communicative competence: An experiment in foreign-language teaching. California: Center for Curriculum Development. 
Savignon, S. J. (1983). Communicative competence: Theory and classroom practice. Massachusetts: Addison-Wesey Publishing Company, Inc.

Septikasari, R., \& Frasandy, R. N. (2018). Keterampilan 4C abad 21 dalam pembelajaran pendidikan dasar. Jurnal Tarbiyah Al-Awlad, 08(02), 109. https://ejournal.uinib.ac.id/jurnal/index.php.

Simarmata, J., Hamid, M. A., Ramadhani, R., Chamidah, D., Simanihuruk, L., Safitri, M., Napitupulu, D., Iqbal, M., \& Salim, N. A. (2020). Pendidikan di era revolusi 4.0. Sumatra Utara: Yayasan Kita https://books.google.co.id/books/about/Pendidikan_Di_Era_Revolusi_4_0_Tuntutan.html.

Slavin, R. E. (1995). Cooperative learning theory, research, and practice 2. Singapore: Allyn and Bacon.

Sugiyarti, L., Arif, A., \& Mursalin. (2018). Pembelajaran abad 21 di sd. Prosiding Seminar dan Diskusi Nasional Pendidikan Dasar, Universitas Negeri Jakarta. journal.unj.ac.id>download.

Sujatmoko, E. (2010). Hak warga negara dalam memperoleh pendidikan. Jurnal Konstitus, 7(1), 190. Doi: https://doi.org/10.31078/jk\%25x.

Trilling, B. \& Fadel, C. (2009). 21st century skills: Learning for life in our times. Amerika: JosseyBass Wiley.

Warsita, B. (2019). Pemanfatan portal rumah belajar untuk meningkatkan kualitas pembelajaran. Jurnal: Teknodik, 23(1), 68-70. http://files1.simpkb.id/guruberbagi/rpp/60371586369405.pdf.

Zed, M. (2014). Metode penelitian kepustakaan. Jakarta: Yayasan Pustaka Obor Indonesia. 